\title{
Transforming Instructional Practice: Two Case Studies of Inquiry-Based Learning
}

\author{
DIANNE OBERG \\ Department of Elementary Education, \\ University of Alberta, \\ Edmonton, Alberta, Canada \\ doberg@ualberta.ca
}

\begin{abstract}
A comparison of case studies of two elementary schools in the United States, in two different Library Power project sites, reveals that the implementation of a new instructional approach such as inquiry-based learning is a complex and multifaceted endeavour. Provision of enhanced collections, improved facilities, full time librarians, flexible scheduling, and professional support was not sufficient for the transformation of instructional practice. Although the two schools appeared to have benefited from similar improvements in resources, only one of the schools demonstrated the transformation in instructional practice that is essential to improved student learning. The roots of this difference appeared to lie in the beliefs held by educators in the two schools about the nature of children, the nature of learning, and the nature of teaching.
\end{abstract}

\section{INTRODUCTION}

At the foundation of the transformation of student learning through inquiry-based learning approaches is teacher transformation. Teachers (including librarians and principals) have to develop personal understanding of the constructivist theory that underpins inquirybased learning. For many educators, this means more than learning about a new learning strategy; it means transforming their deeply-held beliefs and practices related to children, learning and teaching. In this paper, I compare the implementation of the Library Power initiative in two elementary schools in order to develop a deeper understanding of what contributes to the success of such an initiative.

Library Power, sponsored by the DeWitt-Wallace Readers' Digest Fund, was designed to enhance student opportunities for learning through improved school library programs. The Library Power initiative was implemented in over 700 schools in 20 sites across the United States. The National Program Evaluation of Library Power (Zweizig \& McAfee Hopkins, 1999) examined the overall impact of the project. The comparison of the stories of two of these Library Power schools should help researchers and practitioners gain a better appreciation for the potentials and limitations of such projects. 


\section{RESEARCH METHODOLOGY}

Case studies were conducted in each of the two schools in the late 1990s. As case study researcher, I spent at least two weeks at each school site. The case study data were gathered and analyzed using a variety of methods. Field notes were kept to record: observations in the library and in classrooms; interviews with library staff, school administrators, and faculty members; and informal conversations with library media staff, faculty and students. Documents such as lesson plans, schedules, memos, and Library Power reports were collected, as well as student projects such as written reports, stories, and posters. These data were analyzed through content analysis, that is, through a process of reading and re-reading responses, noting the content of responses, identifying themes or categories according to the content, and then grouping and re-grouping the responses within the themes or categories. The comparison study of the implementation of inquiry-based learning in the two schools has been carried out by "re-searching" the data collected for the case studies, using the content analysis approach described above. As often is the case with research of a qualitative nature, the case study data were very rich and offered opportunities for analysis beyond that required for the initial reports of findings for the two case studies.

\section{Inquiry-based Learning in Two Schools}

Comparison of the Context of Two Schools. The two case study schools were quite similar in terms of the communities in which they were located and the overall resources they had available for providing educational programs for their students (see Table 1). Both were located in cities in the southern part of the United States. The populations of the schools were similar in size, in ethnic origin, and insocioeconomic status. The educational programs differed to some degree. Pineview was implementing fewer instructional innovations than was Magnolia. Magnolia appeared to rely more heavily on commercially developed instructional innovations than did Pineview, and textbook use was mandated in Magnolia for most subject areas. For example, in science, while Pineview focussed on hands-on science, complementing classroom science study with science lab work, implemented by a science specialist using locally developed materials and approaches, Magnolia opted for the technology-enhanced Windows of Science series, implemented by classroom teachers. Pineview's instructional innovations seemed more whole-school and whole-class in approach and seemed to focus teachers' attention on student-centered and resource-based approaches. In contrast, several of Magnolia's instructional innovations such as Student Instructional Assistance (SIA) using developmentally appropriate instruction in Gr. K-1 and individualized reading intervention using mentors (HOSTS)--while likely valuable innovations in themselves--did not have a similar philosophical base and they were being implemented as disparate programs. Because Pineview's instructional innovations had a shared philosophical base, the implementation efforts were often mutually reinforcing. 
Table 1

\section{Context of the Two Schools}

\begin{tabular}{lll}
\hline & \multicolumn{1}{c}{ Pineview } & \multicolumn{1}{c}{ Magnolia } \\
\hline $\begin{array}{l}\text { School } \\
\text { community }\end{array}$ & $\begin{array}{l}\text { Blue collar, working class, } \\
\text { urban area }\end{array}$ & $\begin{array}{l}\text { Blue collar, working class, } \\
\text { urban area }\end{array}$ \\
Student body & 530 students, grades K-5 & 425 students, grades K-5 \\
& $75 \%$ African-American & $99 \%$ African-American \\
& $\begin{array}{l}60 \% \text { eligible for free/ reduced- } \\
\text { price school meals }\end{array}$ & $90 \%$ eligible for free/ \\
reduced-price school meals
\end{tabular}

Comparison of the Two Library Programs. The two schools were quite similar in terms of the resources of library staffing, scheduling, and technology but quite different in the way that they used those resources for instructional planning (see Table 2). The largest difference was in the area of instruction-both planning and teaching. Principals in both schools ensured that time was available for collaborative planning by the library media specialist (LMS) and teachers through provision of grade level planning times. The principal at Pineview made it clear to teachers that participation in Library Power initiatives was 
mandatory, and she expected that each teacher plan with the LMS at least three times a year. All teachers at Pineview did some planning with the LMS through the grade level meetings; more than $25 \%$ of the teachers worked in full partnership with the LMS and about $50 \%$ planned with the LMS but got only minimal assistance from her in resource location and/or library instruction. All teachers at Magnolia also did some planning with the LMS through the grade level meetings. The LMS stated that she and the teachers were writing units together but the teachers saw the role of the LMS more in terms of someone who would locate and set aside the resources that they and their students needed for projects.

Table 2

\section{$\underline{\text { Library Programs }}$}

\begin{tabular}{|c|c|c|}
\hline & $\underline{\text { Pineview School }}$ & Magnolia School \\
\hline \multirow{5}{*}{$\begin{array}{l}\text { Qualifications/ } \\
\text { experience of LMS }\end{array}$} & \multirow{2}{*}{$\begin{array}{l}\text { MS (guidance, } \\
\text { counselling) }\end{array}$} & MEd (LMS) \\
\hline & & \multirow{2}{*}{$\begin{array}{l}14 \text { years as LMS in } \\
\text { school, }\end{array}$} \\
\hline & K-12 LMS endorsement & \\
\hline & 17 years as LMS in school, & \multirow{2}{*}{$\begin{array}{l}10 \text { years as teacher in } \\
\text { elementary/middle } \\
\text { classes }\end{array}$} \\
\hline & $\begin{array}{l}\text { previously as HS LMS and } \\
\text { middle school teacher }\end{array}$ & \\
\hline Library support staff & limited & none \\
\hline Flexible scheduling & $\begin{array}{l}\text { Yes (mixed schedule before } \\
\text { Library Power) }\end{array}$ & $\begin{array}{l}\text { Yes (in place before } \\
\text { Library Power) }\end{array}$ \\
\hline \multirow{3}{*}{$\begin{array}{l}\text { Use of Library Power } \\
\text { funds for collection } \\
\text { development, facility } \\
\text { renovation }\end{array}$} & Library resources & \multirow{2}{*}{$\begin{array}{l}\text { Library resources, } \\
\text { classroom series } \\
\text { materials }\end{array}$} \\
\hline & \multirow{2}{*}{$\begin{array}{l}\text { Circulation desk, computer } \\
\text { work stations, storage room } \\
\text { for curriculum materials }\end{array}$} & \\
\hline & & $\begin{array}{l}\text { Reading Teepee, } \\
\text { resource storage/ display } \\
\text { stands }\end{array}$ \\
\hline $\begin{array}{l}\text { Involvement of } \\
\text { teachers in } \\
\text { collaboration }\end{array}$ & $\begin{array}{l}\text { Involvement of all teachers } \\
\text { in grade level planning }\end{array}$ & $\begin{array}{l}\text { Involvement of all } \\
\text { teachers in grade level } \\
\text { planning }\end{array}$ \\
\hline $\begin{array}{l}\text { Role of LMS in } \\
\text { collaboration }\end{array}$ & $\begin{array}{l}\text { Gr. 1-3-instructional } \\
\text { partnership; Gr. } 4-5- \\
\text { provision of resources }\end{array}$ & $\begin{array}{l}\text { Gr. 1-5 - provision of } \\
\text { resources; generation of } \\
\text { instructional idea bank }\end{array}$ \\
\hline $\begin{array}{l}\text { Role of principal in } \\
\text { collaboration }\end{array}$ & $\begin{array}{l}\text { Provision of planning time, } \\
\text { encouragement of LMS/ } \\
\text { teacher collaboration }\end{array}$ & $\begin{array}{l}\text { Provision of planning } \\
\text { time, requirement of } \\
\text { LMS/ teacher } \\
\text { collaboration }\end{array}$ \\
\hline \multirow[t]{2}{*}{ Technology use } & \multirow{2}{*}{$\begin{array}{l}\text { OPAC not yet accessible } \\
\text { Electronic encyclopedia }\end{array}$} & OPAC not yet accessible \\
\hline & & $\begin{array}{l}\text { Laser disk science } \\
\text { materials }\end{array}$ \\
\hline $\begin{array}{l}\text { Involvement of } \\
\text { parents }\end{array}$ & Minimal & Minimal \\
\hline
\end{tabular}


Scenarios of Inquiry-Based Teaching and Learning in the Two Schools. To give a glimpse of inquiry-based learning at the two schools, I have provided four short scenarios, two from Second Grade and two from Fifth Grade, written as part of the case study research. The tone of the scenarios varies because some scenarios were based on direct observation of an inquiry-based learning activity, while others were based on discussions with the teacher, LMS, and the children about an inquiry-based learning activity that had already been completed.

\section{Magnolia School: Second Grade}

\section{Finding Out About Dinosaurs}

Research projects in the second grade classrooms in Magnolia School most frequently grew out of the class work in the language arts anthology (Houghton Mifflin Whole Language Series). Each of the second grade teachers followed the series in a chronological way with her own class. For other aspects of the curriculum, a departmentalized approach was used; the teachers exchanged classes for science, health, and social studies.

This is the pattern that emerged for research projects at the second grade level. The whole class read together the story from what the children called the "anthology" which one child explained as "a book with a lot of stories." For the Dinosaurs project, they read the story Dinosaur Time by Peggy Parrish. After they had read the story, the children went in small groups to the library where they looked at books set aside for them with the LMS. The information they wanted "was easy to find" in the library books. The only book mentioned by title was The Magic School Bus. Some also found information at home, "in the World Book" or "in the dictionary." Each child completed, as his or her final product, a colored picture with brief text which was displayed on the bulletin board outside the classrooms. Some of the pictures appeared to be traced; others, hand drawn. Most of the texts appeared to be sentences directly or nearly directly copied from books.

I asked the children about how they found their information, about what books they used, how they decided what to write on their project, whether they talked to anyone outside of school about their projects, and about what would happen to their projects after they were taken down from the bulletin board. Some children were able to talk about most of these things; some were willing to make only very brief statements. Only one child reported that she talked about her project with friends and parents. Several said that he or she would be taking the project home and that it would be kept "in my room." The children appeared to be pleased to be asked about their work and most, even the least talkative, were able to say something about their final product and something about the process.

\section{Pineview School: Second Grade}

The Tiger Study - Research, Report, Review

The second grade students at Pineview School were studying tigers as part of an animals of Asia unit. They were using a three-step research process model called the Triple $\mathrm{R}$ (Research, Report, Review) developed by a first grade teacher in Pineview School and used by others in the primary grades in the school. The first grade teacher developed the 
model because she believes that children need to get the idea of research early in their school life and that children need to understand that they learn from and can teach others.

The second grade students came to the library as a small group, with small note booklets. The LMS was seated at a table in the reference area ready to greet them, with a globe and a small stack of books. She began with a discussion about the location of Asia. They found Asia on the globe and then began to discuss where they could find information about tigers. They decided to look in the general and animal encyclopedia under "T" - as they found articles about tiger, they began to read aloud sentences from the article. The LMS encouraged them and asked them to find information that they wanted to share. She also read from an article herself, and asked questions to help direct the information search: "What does a tiger look like? How much do they weigh? How do they hunt?" She guided them to form sentences out loud and began to record their sentences on the whiteboard easel. When the board was full, she said, "Before we put this on paper, let's look back and see how we want to organize this." She read the sentences and pointed out the category that the sentence might fit into. Then she asked, "What is best to start out with?' Kristen wanted to start with babies but the LMS suggested they begin with a general description. When the order had been worked out, with some help from the LMS, the sentences were read out in the new order. "Does that flow? Super job!" The students copied their information (five facts) into their booklets and then returned to the classroom. The same basic pattern was followed with three more groups, over the week, each group researching a different animal of Asia. This was the research phase of the Triple $\mathrm{R}$.

The Report phase on tigers took place in the classroom. The teacher announced, "My teachers are getting ready. Students, make sure your desk is clear of everything but your booklet. Your job as students is to ask questions. Here are your teachers. Teachers, are you ready?" The 'teachers' took turns reading their facts about tigers from their booklets. Then, the 'students' asked questions which the 'teachers' answered (with a little help from their teacher). Next, one of the 'teachers' wrote the five facts on the board and the students copied the facts into their booklets while the other 'teachers' moved from desk to desk, monitoring the work. In the midst of this, one 'student 'asked, "Why do tigers live alone?" The teacher repeated the fact that had come from the research phase ("Lions live in groups but tigers don't), but did not appear to probe further. However, later that afternoon, the teacher returned to the topic to carry out the Review phase of the process. The teacher reminded the students of the question raised in the Report phase, and the students shared some of their ideas about the question. One of the student compared the tiger to the panda, an animal studied earlier, and said that the panda was a not a social animal either. One of the students returned to the library to investigate the question with the LMS further, and the process continued.

\section{Magnolia School: Fifth Grade}

\section{African American History Month}

The fifth grade students had been working on their African American History unit before I arrived at the end of February. On Monday moming the class arrived in the library for an introduction to the resources they would need for their project. The LMS began by asking the students to write "Reference" on a clean page. She reminded them that, over the next two weeks, they would be developing a timeline and doing research on a person or 
event in African American history from the 1970s through to the 1990s. She pointed out the Reference collection and helped them define Reference and make a list of the general types of Reference works. Then, she turned to the reference works specific to African American life and history. About a dozen different sources were held up for the students to see and were briefly introduced, along with interjections, questions, references to African American History Month, the Black Rodeo. The last 10 minutes of a 35 minute class focused on the students' suggestions for possible persons and events to research. Then the LMS explained that, when they returned to the classroom, they would be counting off into three groups for their booktalks, one for fiction, one for nonfiction in the $300 \mathrm{~s}$ and $800 \mathrm{~s}$, and one for biography. Over the next two weeks the groups would be coming to the library for help from the LMS.

Later in the week, I observed the students coming in small groups to the library and I talked to several of the students as they worked on their contributions to the timeline. The students explained that everyone had to add a person or event to the timeline and that everyone had to read a book as well for a booktalk to the class. They indicated that they did not usually select their own topics for research. When asked about how they chose their topic for this project, several indicated that they didn't know much about their person or event before they started the research. As I chatted with them about their project, I observed that several were experiencing difficulty in finding information because they were uncertain about which part of a person's name to use in an index or because they did not think of using an index or because they were unaware of other resources available in the library beyond the one they had in hand.

Still later, I interviewed their teacher about the way she and her class use the library. "I'm a stickler for research. Usually they find the topics themselves. They like looking for stuff and they have to use the library more and more for themselves. This class likes to find things for themselves." At my request, she provided two examples of the reports the students were preparing for the timeline project. Sadly, the two samples provided by the teacher from the project showed that sometimes the children's work involved not much more than extracting parts of sentences from a single reference source and combining these sentence parts in the same order as the original source. Both 5th grade samples were paragraphs, approximately 70 words long, identifying an African American man and his most important accomplishment. One sample contained no words or phrases that were not in the original source; the second contained several paraphrases, such as "was released from prison" instead of "walked out of prison" and "many people of all races" instead of "millions of people, black and white."

\section{Pineview School: Fifth Grade}

\section{The Science Fair - The Scientific Method}

The display on the bulletin board across the hall from the science room featured the winners of the school's Science Fair. The science teacher encouraged all fifth grade students to develop science fair projects. Her main goals for the students were learning to apply the scientific method, preparing for middle school (students coming to middle school from other schools would have had science fair experience), and learning to work together. The science teacher did not plan with the LMS in relation to the projects but students were allowed to go 
to the library to find resources related to their projects. The science teacher guided the students in finding project ideas, using the suggestions provided at the end of each chapter in their science textbook, for example, and each project idea had to be approved by her. She provided time in class to work on their projects, and helped them to find materials and to deal with some of the logistical problems. Although this story of student learning does not represent a collaboratively planned unit, it does show student learning that is closer to the expectations for inquiry-based learning than other library-based projects undertaken at the fifth grade level in Pineview School.

The students' projects were very diverse--a wave machine, a car burglar alarm, kinds of filters, effect of kinds of light on plant growth. The students' views of the learning process were drawn from conversations with small groups of students from both grade levels. The students were enthusiastic about their projects and about science "because you get to do stuff." Several mentioned that they had chosen their project because it was something they wanted to know more about, and others mentioned that they still wanted to learn more about the topic. They got their project ideas from their science textbooks, from their experiences visiting the aquarium or science museum, or from their hobbies or club work. Most reported that they began by looking at books and writing down ideas. Once a project idea had been okayed by the science teacher, they found, made, or bought the materials they needed for their displays and demonstrations, often enlisting the help of family members. Then they searched for more information on their idea, using library books and electronic encyclopedias, at home or at school. They often got help from others outside of school. Some reported that they had revised or redone their work because a parent had said that the work was not yet good enough.

The students displayed their projects in class, and they enjoyed the positive response from their classmates. "Everyone clapped and that made us more confident." After the projects were presented to their class and to a third grade class and after the projects had been judged, most students took their projects home. They reported that their families were proud of them. "My dad put [my project] up and he said, 'Did you wow them?"' Several reported that they had received special treats at home as rewards for good work. They reported that they were pleased about their work and proud of their projects. When asked how they knew they had done a good project, they made comments such as, "Other people said it was good" and "It was creative." When asked what they had learned about making a good project, they had lots of suggestions: "Don't waste time, make sure you use the scientific method, work hard, believe you can do it, write neat, speak up when you present your project." Several mentioned the importance of working as a team, of making a display eye-catching, and of thinking of your audience. When asked why they thought their teachers had them develop science projects, they also had lots of ideas:

\footnotetext{
"You learn from it, something you didn't know before."

"It's testing your ability to do research."

"It teaches you to present and to teach others."

"It teaches you to never give up. What doesn't seem interesting then will get more interesting."

"It's helpful to learn new things. Then it's easier to learn later."
} 
"It teaches you organization and you know yourself better."

"It teaches you to know your friends better and to work with a group."

\section{COMPARISON OF INQUIRY-BASED TEACHING AND LEARNING IN THE TWO SCHOOLS}

The two schools were quite different in their implementation of inquiry-based teaching and learning (see Table 3). Both schools had much work to do in terms of developing the kind of inquiry-based learning opportunities envisioned in constructivist pedagogy (Brooks \& Brooks, 1999), in the meaning-making information search process (Kuhlthau, 1993), and in authentic pedagogy (Newmann, Marks \& Gamoran, 1995).

From a constructivist viewpoint, inquiry learning should involve exploration and developing personal connections with what is being learned. From both the constructivist and the information search process perspectives, inquiry-based learning should begin with the children having background knowledge of the topic or developing that background in ways that develop children's interest in and commitment to the topic. Once children have developed their knowledge of and interest in the broad topic, they should be involved in determining what questions will be investigated and how they might find the information they need about a particular topic selected from the broad topic area. Children should be involved in making sense of information, presenting what they have learned in their own words or drawings and/or in other information formats chosen because of their appropriateness to purpose.

These tasks require children to engage in "deep processing," to think about the information they have and the information they want, or to consider how to present information to a particular audience. Finding the desired information, putting it into one's own words, taking notes, organizing the information, and creating a presentation format are the next tasks in the information search process. Finally, when a research project is complete, students should be able to evaluate their learning, both in terms of content and process. They should be able to suggest criteria for evaluating their research product and to identify the steps in their research process. They should understand why their teachers have them do inquiry-based projects. This is part of helping children to understand the information search process. Carrying out research in an in-depth thoughtful way, or engaging in disciplined inquiry, reflects an authentic pedagogy perspective. Also from this perspective comes the view that children, especially older children, should be able articulate the importance of this kind of work for developing their 'learning to learn' skills, and the view that children should be able to see the connections between their inquiry work done in school to work or activities that are done outside of school.

Table 3 compares the implementation of inquiry-based learning in Grades 2 and 5 in Pineview and Magnolia Schools. 


\section{Table 3}

Inquiry-Based Teaching and Learning

\begin{tabular}{|c|c|c|}
\hline & Pineview School & Magnolia School \\
\hline $\begin{array}{l}\text { Use of a research } \\
\text { process model }\end{array}$ & $\begin{array}{l}\text { Gr. } 2 \text { - yes (Triple R) } \\
\text { Gr. } 5 \text { - no }\end{array}$ & $\begin{array}{l}\text { Gr. } 2 \text { - no } \\
\text { Gr. } 5 \text { - no }\end{array}$ \\
\hline $\begin{array}{l}\text { Source of topics } \\
\text { for inquiry-based } \\
\text { learning }\end{array}$ & $\begin{array}{l}\text { Gr. } 2 \text { - curriculum } \\
\text { Gr. } 5 \text { - student generated }\end{array}$ & $\begin{array}{l}\text { Gr. } 2 \text { - reading series } \\
\text { Gr. } 5 \text { - cultural } \\
\text { celebration }\end{array}$ \\
\hline $\begin{array}{l}\text { Student } \\
\text { generation of } \\
\text { research } \\
\text { questions }\end{array}$ & $\begin{array}{l}\text { Gr. } 2 \text { - to a limited extent } \\
\text { Gr. } 5 \text { - to a limited extent }\end{array}$ & $\begin{array}{l}\text { Gr. } 2 \text { - no } \\
\text { Gr. } 5 \text { - no }\end{array}$ \\
\hline $\begin{array}{l}\text { Location of } \\
\text { information } \\
\text { resources }\end{array}$ & $\begin{array}{l}\text { Gr. } 2 \text { - by LMS } \\
\text { Gr. } 5 \text { - by students assisted } \\
\text { by teacher/LMS/ parent }\end{array}$ & $\begin{array}{l}\text { Gr. } 2 \text { - by LMS } \\
\text { Gr. } 5 \text { - by students } \\
\text { assisted by LMS }\end{array}$ \\
\hline $\begin{array}{l}\text { Presentation of } \\
\text { information in } \\
\text { students' own } \\
\text { words }\end{array}$ & $\begin{array}{l}\text { Gr. } 2 \text { - yes } \\
\text { Gr. } 5 \text { - yes }\end{array}$ & $\begin{array}{l}\text { Gr. } 2 \text { - no } \\
\text { Gr. } 5 \text { - no }\end{array}$ \\
\hline $\begin{array}{l}\text { Presentation of } \\
\text { information } \\
\text { adapted to } \\
\text { audience }\end{array}$ & $\begin{array}{l}\text { Gr. } 2 \text { - yes } \\
\text { Gr. } 5 \text { - yes }\end{array}$ & $\begin{array}{l}\text { Gr. } 2 \text { - no } \\
\text { Gr. } 5 \text { - no }\end{array}$ \\
\hline $\begin{array}{l}\text { Evaluation of } \\
\text { research process } \\
\text { and/or product }\end{array}$ & $\begin{array}{l}\text { Gr. } 2 \text { - by teacher } \\
\text { Gr. } 5 \text { - by teacher but able to } \\
\text { self-evaluate when asked }\end{array}$ & $\begin{array}{l}\text { Gr. } 2 \text { - by teacher } \\
\text { Gr. } 5 \text { - by teacher } \\
\text { but able to self- } \\
\text { evaluate when asked }\end{array}$ \\
\hline $\begin{array}{l}\text { Understanding of } \\
\text { the value of } \\
\text { inquiry-based } \\
\text { learning }\end{array}$ & $\begin{array}{l}\text { Gr. } 2 \text { - not assessed } \\
\text { Gr. } 5 \text { - yes }\end{array}$ & $\begin{array}{l}\text { Gr. } 2 \text { - not assessed } \\
\text { Gr. } 5 \text { - not assessed }\end{array}$ \\
\hline
\end{tabular}

\section{FINDINGS BASED ON THE COMPARISONS}

The two schools appeared to have benefited from similar improvements in resources. Both schools had full-time LMSs prior to the Library Power project, but the project enabled both schools to enhance collections, to improve facilities, and to gain greater access to a wide range of professional support for the transformation of instructional practice. It also allowed one of the schools to move from partial to full flexible scheduling. Overall improvements in resources appeared to be necessary but not sufficient for the transformation of instructional practice. Only one of the schools demonstrated to any great extent the transformation of instructional practice that is essential to improved student learning. 
Major changes in student learning such as inquiry-based learning cannot readily occur without teacher transformation (Oberg, in press). The transformation of teachers, principals, and librarians, can be facilitated by: the faculty's history of successful change; the visionary leadership of the principal; the sharing of leadership roles among the principal, the LMS and the teachers; the opportunities for teachers to work together; and the opportunities for teachers to learn together. Comparing Magnolia School with Pineview School on these supporting elements may help us understand why Pineview was more successful in using Library Power as a catalyst to transform instructional practice.

1. Faculty Capacity for Change: A faculty that has had experience of successful instructional innovation will be able to do the transformative work required for another new instructional innovation. Pineview's success with curriculum alignment and hands-on science made its success with inquiry-based learning more likely. Magnolia had tried many instructional innovations; it had failed in at least one (portfolio assessment), and was struggling with many new innovations competing for attention and resources. A faculty with experience of failed innovation will need greater support, time, and encouragement to be able to address a complex instructional innovation such as inquiry-based learning.

2. Instructional Leadership of the Principal: A principal can use routine administrative structures to emphasize teachers' use of the library, to encourage collaboration between the teachers and LMS, and to reinforce student-centered teacher practice. The experienced principal at Pineview was dynamic and forceful and knowledgeable about her school district and community; she used her focus on student learning to build support for inquiry-based learning in the school and in the community. The novice principal at Magnolia had strong academic credentials but was much less knowledgeable about her school district and community; she was unable to reduce the proliferation of innovations.

3. Shared Leadership within the School: The teamwork of the principal and LMS can enable an instructional innovation such as inquiry-based learning to be implemented in a powerful way. The leadership of classroom teachers in Pineview - as well as that of the principal and the LMS - was important in implementing inquiry-based learning. The LMS and principal at Magnolia did not support each other. For example, the principal gave the task of developing an information scope and sequence to another teacher on staff, and the LMS did not offer her support to the principal's efforts to change teachers' thinking about their teaching in relation to the Library Power initiative or to the SIA initiative. The leadership from classroom teachers that appeared to have emerged was not focused on the implementation on inquiry-based learning.

4. Collaboration: Schools that are places where people share their ideas and where there are structures in place to facilitate teachers' working together are more able to implement an instructional innovation such as inquiry-based learning. Flexible scheduling provides the opportunity for teachers to use the library in a more integrated way and to work together to develop a deeper understanding of inquiry-based learning. Both schools had implemented flexible scheduling and grade level planning. The difference was in the nature of the planning. In 
Magnolia, the LMS and the teachers, brainstormed possible activities to include in a unit plan; in Pineview, the actual teaching and learning process that would be used by the LMS and the teachers to carry out the unit plan with the students was directly addressed in the planning sessions.

5. Teacher Learning: Staff development is critical for the implementation of an instructional innovation such as inquiry-based learning; staff development is more powerful if it is clearly focussed on the innovation and part of the instructional practice of the school. Pineview had a long history of involvement in professional development at the district level; Pineview faculty members were also accustomed to having professional development activities as part of their regular monthly staff meeting. Pineview faculty were involved in national and local Library Power workshops, they visited other Library Power schools, and they provided workshops for other schools about the Library Power initiative. Magnolia faculty were also involved in national and local Library Power workshops; however, they also were involved in professional development related to other innovations being implemented in the school. Although the Magnolia staff spent more time overall in professional development than did the Pineview faculty, much of it was not focussed on Library Power.

However, differences in these supporting elements do not tell the whole story. There were also real differences in the deep-seated beliefs held by educators in the two schools about the nature of children, the nature of learning, and the nature of teaching. The faculty at Pineview believed that all children are able to make good choices for themselves and that teachers need to support children in their choices. For example, when asked about the future of changes brought by involvement in Library Power, at least four different faculty members stated, "The kids won't let us go back!" A fifth grade teacher said, "The integrated approach will not disappear. There has been a change of attitude in our children. They feel that they have the power, and the teacher is there helping them. These children are not afraid to leam." The assistant principal observed that children "take more pride in their learning when they have some input into their own learning."

The faculty at Magnolia were less likely to believe that children are able to make good choices for themselves and at time actually prevented children from making their own choices. For example, when students came to the library to select materials, they were expected to select resources from designated categories: there was a section of picture books forGrades $\mathrm{K}-1$, one for Grade 2, and one for Grade 3. The remainder of the circulating collection was designated for Grades 4 and 5. Videos and magazines could not be borrowed by students and only a very few paperbacks were available. Students who tried to select resources outside the categories designated for them were reprimanded. The LMS and teachers did not appear to see this practice as limiting students in anyway. It was also quite revealing that the first draft of the school's information skills scope and sequence, based on their state document, omitted skills related to student choice such as "Begins use of card catalog," "Selects materials appropriate to reading level," and " Selects print and nonprint materials for satisfaction of personal interests." Teachers at Magnolia did not seem to believe that all children could be successful. For example, some teachers spent a lot of time and energy with a few students who were competing in essay contests or science fairs. Promising students seemed to be selected by teachers to do these special projects, and the 
teachers then assisted them to produce very good projects by buying supplies for the students, typing up the students' reports, and designing labels and headings for the students' poster presentations or displays.

Faculty at the two schools differed in their beliefs about teaching. The faculty at Pineview believed that teaching was about learning new approaches and about changing beliefs. A third grade teacher said, "I hope that we continue and keep growing. ... We feel the library is open to us. We are less tied to the textbook and more willing to take a chance, to develop new approaches." A first grade teacher observed, "The Library Power changes are deeper than the things, the materials, although they were certainly a boost, an encouragement and the changes could not be implemented without the materials. Library Power supported a change in the philosophy of teaching. It brought a totally different view of the library, and it caused teaching here to open up. It feels like you came from 'seeing darkly' to a space full of light." The faculty at Magnolia rarely expressed views about the nature of teaching. The educational culture within which the Magnolia teachers worked appeared to give many messages that they as teachers could not be expected to be independent and to make good decisions about what and how to teach. At Magnolia, textbooks and supporting materials were prescribed for most subject areas (including whole language); at Pineview, textbooks were just part of the wide range of resources used by teachers. At Magnolia, standardized test results appeared to be viewed as providing the most valid assessment of student learning and of school performance; at Pineview, standardized test results were viewed as only one measure of student learning and school performance.

\section{CONCLUSIONS}

The roots of the differences between the two schools appear to lie in the beliefs held by educators in the schools about the nature of children, the nature of learning, and the nature of teaching. To develop inquiry-based learning requires more than structural changes in schools; it requires transformation of both beliefs and practices related to learning and teaching. The development of inquiry-based learning requires that principals, LMSs, and teachers hold student-centered, constructivist views of learning and that they transform their practice in ways consistent with inquiry-based learning. Changes in instructional practice are often difficult to sustain over time. Even with changes in the beliefs and practices of educators, support for the institutionalization of the changes in practice that are fundamental to inquiry-based learning will involve such factors as external support, policy, leadership, staff development, and funding. However, without changes in the beliefs and practices of educators, improvements in external support, policy, leadership, staff development, and funding are not likely to improve student learning.

\section{REFERENCES}

Brooks, J. B., \& Brooks, K. G. (1999). In search of understanding: The case for constructivist classrooms. $2^{\text {nd }}$ ed. Alexandria, VA: Association for Supervision and Curriculum Development.

Keedy, J. L., \& Achilles, C. M. (1997). The need for school-constructed theories in practice in US school restructuring. Journal of Educational Administration, 35 (2), 102-121. 
Kuhlthau, C. C. (1993). Seeking meaning: A process approach to library and information services. Norwood, NJ: Ablex.

Newmann, F. M., Marks, H. M., \& Gamoran, A. (1995). Authentic pedagogy: Standards that boost student performance. Issues in Restructuring Schools, Center on Organization and Restructuring of Schools, University of Wisconsin-Madison, Issue Report No. 8.

Oberg, D. (in press). Teacher transformation. In J. Donham, K. Bishop, C. Kuhlthau, \& D. Oberg, Inquiry-based learning: Lessons from Library Power. Worthington, $\mathrm{OH}$ : Linworth. Zwiezig, D. L., \& Hopkins, D. M. (Eds.) (1999). Lessons from library power: Enriching teaching and learning. Englewood, CO: Libraries Unlimited. 